\title{
5 \\ Kanak Women on the Move in Contemporary New Caledonia
}

\author{
Marie-Claire Beboko-Beccalossi'
}

\author{
Les femmes ont une place importante \\ à prendre (dans la société), \\ elles sont une richesse dans l'évolution du pays. ${ }^{2}$ \\ Marie-Claire Beccalossi
}

\section{Editors' preface}

This text was sent to us on occasion of the 7th ESfO conference in Verona, and was read by Christine Jourdan at the round table. It was accompanied by an email from Marie-Claire Beboko-Beccalossi, 'Alors que tu t'apprêtais à me recevoir à Vérone pour cette rencontre que tu fignoles depuis un moment déjà, voilà que je te fais faux bond; sois sûre que si ma santé était sans accros, je serais venue vous rejoindre là avec grand, grand plaisir. Bonne rencontre, Bonne conférence! Je suis de tout cœur avec vous'. ${ }^{3}$

\footnotetext{
1 This text is the translation of the Italian version that was assembled by Silvia Bernardi from the notes sent by Marie-Claire for the ESfO conference, 'Les femmes de Nouvelle-Calédonie', March 2008, Verona.

2 Women have an important place in society, they are wealth for the country's evolvement.

3 Just as you were preparing to welcome me in Verona for this meeting which you have been nurturing for some time, I must let you down; rest assured that if my health were not problematic, I would have joined you there with great, great pleasure. Have a good meeting, a good conference! I'm with you with all my heart.'
} 
Unfortunately, Marie-Claire's illness proved to be fatal, and when we published her notes in Italian in the journal la Ricerca Folklorica (Paini and Gnecchi-Ruscone 2011: 63) Anna Paini consulted with her husband, Ermenegildo Beccalossi, who commented on the translation in the following email:

I have read through the original French text and the hand written corrections added by Marie-Claire. I find that the translator/s have done a commendable job of coordination and comprehension. To help capturing and understanding a text by Marie-Claire, I take the liberty of underlying some elements. Marie-Claire came from an oral culture, she had a great ease with speech, and her writings go through unforeseen changes and also repetitions which could have weighed down the translated and published text, especially for readers who are unfamiliar with the person and her country (31 October 2011).

Marie-Claire Beboko-Beccalossi was recognised as a prominent figure for Kanak women; she devoted her life to social justice and women's rights in the Pacific area. Her life history shows a record of commitment and struggles to give Pacific women a voice, a face and political representation. She was active on several fronts at both local and regional levels, but also internationally: as a young woman she militated in Jeunesse Agricole et Rurale Catholique des Femmes (JARCF), becoming its president, and later in life she participated in the Pontificial Council for Justice and Peace.

The notes that compose this chapter constitute Marie-Claire's personal account of the crucial passages of indigenous women's struggles in New Caledonia from early colonial days to the present. In particular, it underlines the role of the younger generation of women of the 1960s-70s in the establishment of women's groups (both confessional and secular organisations), to which older women participated only at a later stage, giving rise to networks which enabled Kanak women to endure the upheaval of the Evénements in the 1980s, showing their resilience in the pervasive tensions and conflicts of the period.

This chapter focuses on issues that were close to her heart, placing Melanesian women at the centre; she held that Kanak women have been and still are agents of change and innovation and, above all, they 'hold their heads high'. 
We believe these pages exemplify the passion, commitment and vision constituting her lasting legacy.

\section{Before the Great War}

A bird's-eye view over the traditional Kanak world during colonial times reveals the novelty represented by the space devoted to women's collective activities within the tribes and around places of worship, under the influences of Catholic and Protestant churches. Religion undoubtedly provided a stimulus for the formation of groups and collective moments. Away from their customary obligations and from habits and impositions of the male world, these new forms of encounters have helped women to understand and acquire new knowledge: they were able to satisfy their curiosities, to exchange and use new materials; they have diversified their cooking skills and their household management, they have learned to sew, mend and even a new language: the language of whites, the idiom that had kept them at a distance from many activities of colonial society.

Some girls were even able to engage in learning reading skills and 'French style' good manners: depending on their rank in traditional society, these young women have profited, by choice or imposition, from the teaching and education given by nuns and the wives of the pastors. The ecclesiastical communities have thus given rise to the formation of long-term learning groups for Kanak girls and boys. A sort of private school, still at the embryonic stage, yet complete with all the prohibitions brought by the new way of life: the prohibition to speak one's own language in favour of French, for example, was essential for moving from the 'savage' to the 'civilised' condition. Undoubtedly in this phase the assimilation of French culture was inflected almost exclusively through imitating white people's behaviour, that is 'acting like the white man', like the kamadra (Drehu). ${ }^{4}$

The event which gave a jolt to this way of thinking, based on a single model - the kamadra model—and that has deeply affected Kanak mentality, is World War II: many young Melanesian volunteers left for the front encountering unknown lands, radically different from their own, while the presence of Americans in New Caledonia produced an unprecedented situation of encounter with the other. The war was thus

4 This Drehu word, kamadra, is widely used throughout New Caledonia; it means 'white person' (editors' comments). 
a situation of conflicts but also of encounters, as shown by the tales and memories of the young volunteers who returned: families and whole tribes listened with amazement to the incredible stories told by their sons, and learned of women's involvement on the battle ground.

Despite the blood, pain and losses, the war had multifaceted implications, it created the circumstances for recognising a new form of warrior with very different qualities from those that were traditionally known.

The steps leading to social changes are very slow; as I had the opportunity to recall during the International Women's Day celebration of 8 March 2007:

The day before yesterday our great grandmothers moved from silence to speaking, within the family and among themselves within the different clans. Yesterday our grandmothers moved from speaking to representing, within the family and the clan.

\section{The 1950s: From colonisation to participation}

World War II thus marks an important moment for Melanesian society. New Caledonia is shaken by impulses that profoundly change the structure of society. New associations are formed which are organised according to religious and political leanings. Assemblies, increasingly characterised by a secular approach, involve groups of women, youths and intellectuals. At the same time, periods spent abroad for studying or to acquire an appropriate education for modern times become more common, and in the following decades many students, both girls and boys, leave to spend a length of time in France and other foreign countries.

If today education and training are a priority in the context of the Cadres Avenir project within the Matignon and Nouméa Accords, in the 1960s such an opportunity was an absolute novelty. It is not surprising that initially the establishment of new women's organisations was structured around the initiatives and spontaneity of the younger girls, often returning from a period of study abroad. Later they were flanked by women gathered in confessional associations and federations, as well as in secular NGOs. It is precisely in this lively historical moment that I had the opportunity to live my first experience within a great federation. In 1963 I was elected President of the Jeunesse Agricole et Rurale Catholique des Femmes (JARCF), a women's organisation which at the time had over 3,000 Kanak members. I held this position until my marriage, six years later. 
It is true that, on the one hand, for two-thirds of last century the activities of Melanesian women's groups adopted the west as a model of civilisation, a partial heritage of colonial history. On the other hand, all the movements demonstrated the evident will of Kanak women to take a further step on the path towards their rights: a step towards representation and social participation. The mouvement féminin vers un Souriant Village Mélanésien (mfSVM), established in 1972, is a good example of such a gradual process of affirmation of Kanak women's groups in New Caledonia.

\section{From social to political participation: The 1980s and 1990s}

In the 1980s New Caledonia is a territory that lives neither in peace nor at war: tense, restless, lively, the island is crossed by a series of intense upheavals aiming at independence from the French government. At middecade, the FLNKS movement (Front de Libération Nationale Kanak et Socialiste) headed by Jean-Marie Tjibaou, leads the struggle for the autonomy of Melanesians ${ }^{5}$ from the caldoches $^{6}$ living on Kanaky. ${ }^{7}$

5 The term Melanesians here is translated directly from Marie-Claire's French notes to reflect the practice, common in New Caledonia in the recent past, to label as Mélanésiens only Kanak (see, for example, Census (New Caledonia) 1989 and National Institute of Statistics and Economic Studies (INSEE) (1997) (eds comments).

6 Caldoches designates the descendants of European convicts and colonists settled in the country over several generations (eds comments).

$7 \quad$ Kanaky is the name given to New Caledonia by Kanak independentists and widely adopted in the country. Some people believe that once the country achieves a new political status it should be renamed Kanaky New Caledonia.

For a better contextualisation, we mention here the events of the tormented colonial history referred to in this chapter. New Caledonia, a French possession since 1853, was a penal colony before becoming a settlement colony. After World War II it became a French Overseas Territory (TOM). In the 1980 s the country was traversed by deep-rooted political tensions between Kanak and caldoches (les événements). The Matignon Accords (1988) created the conditions for a new climate in the country. A process of decentralisation provided for by the Matignon Accords was initiated to balance the social and economic gap between the capital Nouméa, a prevalently white centre, and the rest of the country, mainly inhabited by Kanak, resulting in the institution of three provinces: the Loyalty Islands Province, the Southern Province and the Northern Province. The referendum on the political future of the country foreseen in the Accords for the end of the 1980s was made obsolete by the Nouméa Accord of May 1998, which gave more autonomy and a new denomination to the country, collectivité sui generis. The referendum on self-determination has now been rescheduled for 2018 (eds comments). 
The Matignon Accords, at least partly, placate the revolts. This did not stop the achievements of women in government agencies, and thus their growing visibility in the political arena. A historical date is 1983: the first Bureau Technique des Femmes (BTF) was instituted at the SPC, ${ }^{8}$ followed just a few months later by the Conseil des Femmes de Nouvelle Calédonie (CF.NC), an outcome of women's expectations and their growing autonomy. As the head of the BTF and as regional delegate to the Council of Ministers of the French government, I invested all my energies in a project calling for the establishment of the Office for Women's Rights in New Caledonia. With great satisfaction on the part of my colleagues and me, the project was approved by the government, and soon the office came to life. Once this service was created it recruited some women; they went on to form the New Caledonia Regional Delegation for Women's Rights. At last I was no longer alone, even when facing the Council of Ministers.

The early 90s were devoted to working towards further reforms in the wake of the previous successes. Most of the women's associations of all the provinces gathered in councils, thus gradually widening their sphere of competence. If, on the one hand, the new Nouméa Accord of 1998 has disappointed the expectations of most of the population by postponing the date of the pro-independence referendum to the fourth term of the Congress, on the other hand it has ratified a further strengthening of the country's prerogatives for autonomy, thus progressing towards a gradual hand over. Women's organisations wish to seize the opportunities offered by the Accord, working towards the best conditions for an administration that would respect every community in the country.

\section{The significance of 3 June 1983}

Following an invitation which I extended as head of the BTF for the Community of the South Pacific, more than 70 coordinators of religious and secular women's associations gathered in a large assembly on 3 June 1983. My aim was, first of all, to raise awareness of the Bureau Technique des Femmes, that had been established only three months before within the

8 SPC is the principal scientific and technical organisation in the Pacific region. It was founded in 1947 under the Canberra Agreement. Although the acronym has never changed given its widespread use across the Pacific Islands region, the name has changed over time from South Pacific Commission, to Secretariat of the Pacific Community, to Pacific Community (2016) (eds comment). 
SPC regional service alongside its sister English-speaking section. Second, I wanted to encourage the different representatives to meet in order for them to equip themselves with a structure of dialogue, that should be at the same time representative of the entire female population of the Territory (New Caledonia), but also a means of mediation between the different local and central administrative powers. I should emphasise that these goals were undoubtedly in syntony with the requests of the United Nations, which were recommending to offices and structures such as the BTF and the SPC to promote and support women's organisations in each country, so that women could make their voice heard and cooperate in order to solve problems concerning education, health and employment.

Each of the coordinators attending the meeting took on the message of the conference, welcoming it with great enthusiasm; the atmosphere was one of conscious participation. All the women were aware of the importance of the decisions stemming from the meeting, to the point that on the following day, 3 June, they all agreed to give life to the Conseil des Femmes de Nouvelle Calédonie (CF.NC, Council of Women of New Caledonia), and they chose that day as the date of the first General Assembly. Mme. Léontine Ponga, a member of the Christian Women's Movement, was the first chairwoman to be appointed. Year after year the activities of the organisation proceeded with tenacity and determination, fulfilling its decisions, without ever resorting to having to applying for public subsidies.

\section{The history of a name: From the Council of Melanesian Women to the Federation of Melanesian Women's Associations of New Caledonia}

The tormented times of revolts and struggle, however, were just around the corner. Soon after the country was deep in rivalries and resentments, different ethnic groups regarded each other with suspicion, and the two main political alliances fought like bitter enemies. Such a climate of tension inflamed people's minds, and eventually it infiltrated within the women's council. Many among the association leaders ceased taking part in the meetings, and those who did attend brought with them proposals that were biased by their political sympathies. 
At a time like that it would have been easy to lose heart and hope. However, among all the difficulties of that scene, my colleagues and I were motivated to move forwards by the awareness that Kanak women were still there: they resisted, and, for a long time they had been the only ones to do so. Realising that, we decided to rename the Assembly in order to highlight their constant presence and give it a 'a truer face', more congruent to the actual composition of the structure: a name that was in use from 1989 to 1995. Thus was born the Council of Melanesian Women of New Caledonia (CFM.NC), a transitional organisation before the establishment of the Federation. ${ }^{9}$ According to many of us, we were still struggling to find an adequate way for our purposes to develop, and it appeared that the Council's orientation should change once more: the executive agreed that a single organisation was necessary to represent women from different ethnic groups living in the country, and to coordinate such groups among themselves and with others from other nations. We also aimed at creating a non-party, multi-confessional assembly with a clear ethnic identification of its membership - a membership that would be able to bring strength to the movement as a whole without discriminating against others in any way, allowing different ethnic groups to establish similar associations, and to bring their contribution within their own council.

The new organisation thus took the name of Federation of Melanesian Women's Associations of New Caledonia (FAFM-NC), a name that is still in use.

\section{Developments of the new millennium}

The Federation today is highly regarded in the panorama of international NGOs. Thanks to its longevity and extensive presence in the territory, it is recognised by other organisations as well as by the government offices relating to women's conditions and roles. Besides defending their rights and interests, today's goal is that of promoting economic, social and cultural exchanges with women from other associations, also beyond New Caledonia: because to build networks implies first of all creating potential alliances.

9 The Council of Women of New Caledonia was open to all women's organisations in the country, while the Council of Melanesian Women of New Caledonia gathered indigenous groups of women (eds comment). 
Pivotal to the FAFM-NC's resolutions is the search for individual and collective autonomy within the groups that are active in the country and the promotion of forms of development centred on the human being-development that responds to real needs as expressed by the communities living in tribal settlements. Among the government structures responsible for the protection of these principles, today there is a new office: the Observatory for the Condition of Women, to which I belong as representative of the Federation. The main mission of this new body is aimed at the redefinition of Kanak women's roles within their society, at education and professional training for women. It includes also the elaboration of information and communication strategies for the empowerment of women (through the yearly event of the International Women's Day and the publication of the Federation's Nouvelles), and the drawing up of a Convention on the Elimination of All Forms of Discrimination against Women (CEDAW) in New Caledonia.

\section{Holding our heads high}

We are living in an era in which each society must necessarily face up to deep changes, and New Caledonia is certainly no exception. Day after day we realise the complex implications of globalisation, transforming our way of thinking about history and of framing the flow of our lives. We are unavoidably faced by this challenge: in recent times our country has witnessed the spread of modernity and the advancement of women's movements. Kanak women have demonstrated a remarkable ability to adapt to social changes, often greater than that of Kanak men. Globalisation has drawn them into a tumultuous cross-cultural civilisation, which can enrich them if they take the time to appreciate it, analyse it, understand its potential, and absorb it without losing themselves. With few means but great fortitude, Kanak women are trying to make room for themselves in an ever-increasing number of professional and social sectors, proving their flexibility, pragmatism and resoluteness. One of the best-known examples, in this regard is their employment within the three large nickel plants on the main island. ${ }^{10}$

10 For a history of the nickel industry in New Caledonia, see Bencivengo (2014) (eds comments). 
New Caledonia today is thus the image of its inhabitants, eight different ethnic groups that share and live on the same land. ${ }^{11}$ Each feeds on the others' cultures: food, clothing, languages, places, feasts and so on, but each of them, independently from the others, claims its origins with firmness and dignity. All this is possible thanks to the processes of adaptation that the New Caledonian society has been able to engage in, seizing those valuable chances for growth that integration is always able to offer. Girls in particular have thrown themselves enthusiastically into the training opportunities arising from the new economic system and the development projects within the country (Paini 2007).

The women of New Caledonia are thus on the move, they move ahead at great speed, but most of all they hold their heads high.

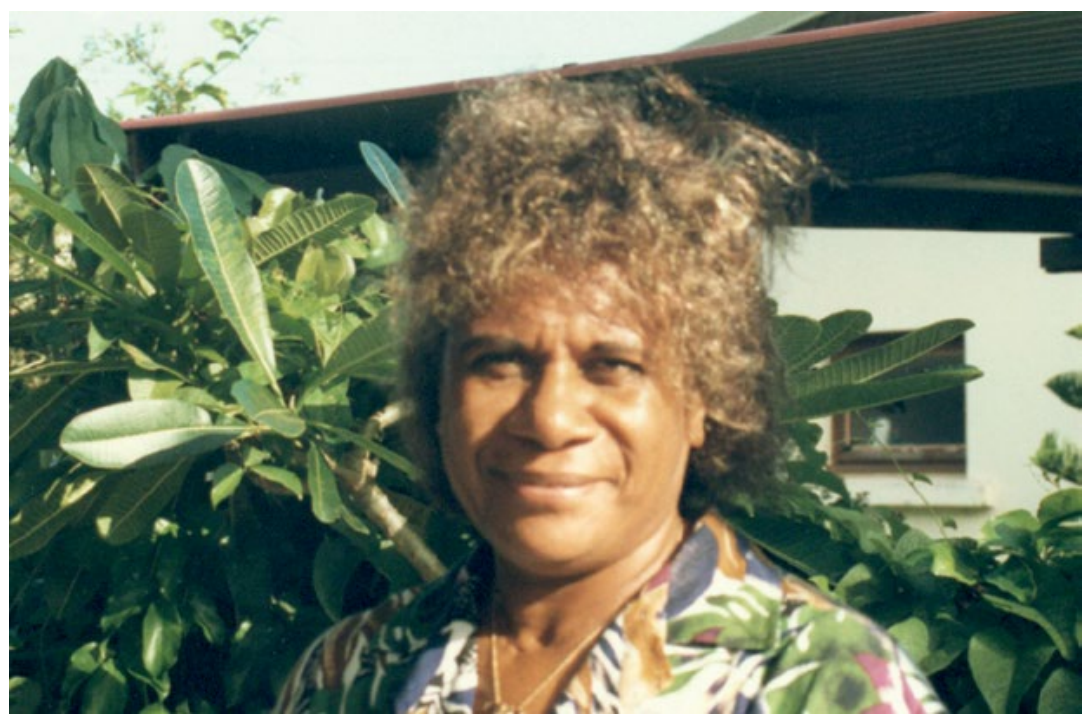

Figure 29. Marie-Claire Beboko-Beccalossi (24 February 194229 March 2009)

Source. Photographed by Anna Paini, Nouméa, 28 March 1992

11 'Ethnic groups' is a term commonly used in New Caledonia to refer to the different nonautochthonous communities living in the country (eds comments). 


\section{References}

Bencivengo, Yann. 2014. Nickel. La naissance de l'industrie calédonienne. Tours: Presses universitaires François-Rabelais.

Census (New Caledonia). 1989. Recensement de la population 1989. Nouméa: Institut territorial de la statistique et des etudes economiques.

Convention on the Elimination of All Forms of Discrimination against Women (CEDAW). 1979. Online: www.un.org/womenwatch/daw/ cedaw/cedaw.htm (accessed 30 December 2015).

National Institute of Statistics and Economic Studies (INSEE). 1997. Images de la population de la Nouvelle-Calédonie. Principaux résultats $d u$ recensement 1996. Paris: Imprimerie Nationale.

Paini, Anna. 2007. Il filo e l'aquilone: i confini della differenza in una società kanak della Nuova Caledonia, Torino: Le Nuove Muse.

Paini, Anna and Elisabetta Gnecchi-Ruscone (eds). 2011. Putting People First. Dialogo interculturale immaginando il futuro in Oceania. Special Issue of La Ricerca Folklorica 63 (April): 3-105. 
This text is taken from Tides of Innovation in Oceania: Value, materiality and place, edited by Elisabetta Gnecchi-Ruscone and Anna Paini, published 2017 by ANU Press, The Australian National University,

Canberra, Australia. 